\title{
COMPETENCY-BASED INTERVIEW PROCESS AND ORGANIZATIONAL PRODUCTIVITY: A STUDY OF SELECTED PRIVATE SECTOR ORGANIZATIONS IN ANAMBRA STATE
}

\author{
${ }^{1}$ Ogbu K. C., ${ }^{2}$ Ewelike U. E. and ${ }^{3}$ Udeh C. J \\ ${ }^{1}$ National Health Insurance Scheme, Anambra State, Nigeria. \\ ${ }^{2}$ Dept. of Informal sector, National Health Insurance Scheme, Abuja, Nigeria. \\ ${ }^{3}$ Dept. of Business Administration, Nasarawa State University, Keffi, Nigeria.
}

\begin{abstract}
The study examined the effect of competency-based employee interview process on organizational performance, using selected private sector organizations in Anambra State, Nigeria as the study area. The literature of the study was segmented into four main sections namely; conceptual review, theoretical framework, theoretical exposition and empirical review. The study adopted descriptive survey design and from a population of 1957 senior members of staff identified from the selected firms across three industrial zones of Awka, Onitsha and Nnewi in the state, 332 population sample was investigated. Statistical tools of analysis were Pearson Correlation and multiple regression analysis. All tests were conducted at 0.05 level of significance. Major findings indicate that competency of use of unilateral power as well as competency of positive regard have positive and significant effect on firms' productivity. The study concludes that competency-based employee interview model, enables organization to appropriately select and place employees where their comparative advantage is highest to enhance performance in the organization. It was recommended among others that managers/management should endeavour to always use the competency-based employee interview process for all their employment purposes.
\end{abstract}

KEYWORDS: competency-based employee interview model, organizational productivity and unilateral power.

\section{INTRODUCTION}

In this age of 'knowledge worker', human resource is the most critical factor for the continued success of organizations both in the public and private sectors. No matter the level of sophistication of the technology in the organization, it will require human know-how for it to be put to use. Rohtas, Sarang, Jagdale, Ajay and Jaiy (2013) opine that despite the huge sums of money organizations spend on research and technology acquisition, businesses are still failing and performing below expectations. It underscores the need for qualified personnel to be recruited in the organization through an effective process that can reveal both the obvious and hidden abilities of the prospective employees.

In the opinion of Miller (2000), providing a high quality and valued contribution to a business requires a range of skills and knowledge and above all, professionalism that is recognizable. Employees need to be professionally qualified to be able to provide a needed service to the business. One of the proponents of competency model, Mchagan (1996) attributes the surge in interest for competency test to several factors. The first is percentage of workforce today that is doing knowledge (competency)-intensive work. The second is the interest in competencies which is rising in direct response to cost and competitive pressures in industries and 
organizations. Whatever the work, competent people are more productive (Simonsen and Smith, 2007).

Modern organizations who understand the need, use their personnel to compete and the critical factor is the employee competencies. A pre-knowledge of the factors will assist the human resource manager in hiring the right personnel. Recruitment exercise is delicate and therefore it cannot be handled with kids glove because mistakes are usually very costly to the organization in terms of deficient performance. Infact, to Maile (2007), both the organization and the candidate have a lot to lose if an interview eventually ends up in an improper selection of employee. The loss is usually found in the areas of training cost and salary/wage spent on the incompetent employee, cost of another recruitment for replacement, cost of training the replacement and low performance of the replaced employee. Marchington and Wilkonson (2006) also warned that poor selection of employee due to wrong process can be catastrophic to business performance and as such it should be avoided. This is because, its potential negative effects on customer service and product quality is significant.

The reason for shifting from the old method of recruitment to the modern method has been explained by Simonsen and Smith (2007) when they pointed out that organizations are moving or changing so fast that there is less time now than ever to hire "green horns" and develop them to meet the organization's expectations by fitting into the organization's culture. The use of competency-based interview enables the human resource manager to hire the right persons on both their aptitude and attitude. Competencies predict performance better than experience. Akinnukawe (2005) added that competency-based assessment allows companies to find better candidates and assures that the people are put in positions best suited for them in the organization. On this note, this study examines the influence of competency based interview process on organizational productivity, with particular reference to competencies of use of unilateral power and that of positive regard. Observe, however, that the competency of use of unilateral power has to do with using forms of influence to obtain compliance from colleagues or subordinates while that of positive regard has to do with having a basic belief in others; freely or easily, sometimes making quick or snap decisions.

\section{Statement of the Problem}

The poor performance of some private sector organizations has been a source of worry to the owners of such firms. The problem ranges from low productivity to low sales of product, to the extent that some of them have become insolvent (bankrupt). While some have attributed the problem to lack of necessary infrastructure and inadequate access to credit facilities, others think the problem has to do with personnel incompetency. The proponents of the later opinion have done a study that examined the effect of competency-based recruitment exercise on the organizational performance, using a non-parametric statistical tool of analysis and found that the method was significantly related to organization's high performance rate. But in a related study, the effect of competency process on the procurement of employees on performance in private sector organizations in Chiba City, Japan was carried out and it was found that the competency model of recruitment did not necessarily translate to improved organizational performance.

In the light of the above conflicting reports, the need to carry out another which will use a parametric statistical tools of analysis, has become necessary to mediate between the 
conflicting reports as well as identify other factors which may be responsible for the poor performance of firms in the private sector of the Nigerian economy. This is what the study sets out to achieve by studying selected private sector firms in Anambra State, Nigeria.

\section{Objectives of the Study}

The broad objective of the study was to examine the effect of competency-based interview model on organizational productivity, using selected private sector organizations in Anambra State as the study area. However, the specific objectives of the study are to:

(i) Evaluate the effect of competency of use of unilateral power on organizational productivity in Nigeria.

(ii) Determine the effect of competency of positive regard on organizational productivity in Nigeria.

\section{Research Questions}

The following research questions were raised to guide the objectives of the study:

(i) What is the effect of competency of use of unilateral power on organizational productivity in private organizations in Anambra State, Nigeria?

(ii) How does the competency of positive regard affect productivity of the organization in private organizations in Anambra State, Nigeria?

\section{Hypotheses}

The following null hypotheses were formulated to guide the objectives of the study and strengthen the analysis:

(i ) Competency of use of unilateral power does not have positive and significant effect on organizational productivity in private organizations in Anambra State, Nigeria.

(ii) Competency of positive regard does not have positive and significant effect on organizational productivity in private organizations in Anambra State, Nigeria.

\section{Significance of the Study}

The study has both theoretical and empirical significance. As a relatively new area of interest in human resource research, the study will add substantially to the existing stock of literature thereby increasing/expanding the frontiers of knowledge in the area. From the empirical perspective, the findings of the study will be of immense benefit to specific categories of people among whom are the management of the organizations, employees, general public and students/researchers.

1. The management will be given insight on how to benefit from competency-based interview model to improve the fortunes of their organizations.

2. The employees will be enlightened on how to easily identify their respective competencies which will enhance their competitive advantage anywhere they found themselves both in their present employment and other places.

3. The general public will benefit from the enhanced productivity that will come as a result of efficient and effective utilization of human resources.

4. The students or researcher who might want to carry out further studies in this area will find the report very useful because it will serve as base data for their study. 


\section{Scope of the Study}

The study covers private sector organizations in Anambra State, Nigeria. On a general note, the effect of competency-based employee interview model on organizational productivity was investigated. However, the specific competencies are the use of unilateral power and positive regard. Their respective elements are using forms of influence to obtain compliance such as charismatic leadership and having a basic belief in others; freely or easily. Sometimes making quick or snap decision.

\section{REVIEW OF THE RELATED LITERATURE}

\section{Conceptual Review}

Within the sphere of conceptual review, major concepts in the study were reviewed. Accordingly, competency framework can be defined as clusters or groups of competencies covering all key jobs or roles in an organization with each cluster covering sets of jobs in a job family requiring similar skills or competencies but applies at different hierarchical levels (Boyatzis, 1982; Armstrong, 1998; Torrington, Hall and Taylor, 2005). Within each of the competencies within the cluster, there are list of behaviours which are classified as positive or negative indicators. Torrington et al., (2005) further note that competency profile identifies and describes the competencies critical for successful performance in a job, within a specific functional area and at a specific level. Each competency in the profile is defined and accompanied by statements of behaviour which describes standards of performance to which the incumbent should aspire.

Lucia and Lepsinger (2009) defined competency as the capability of applying or using knowledge, skills, abilities, behaviours and personal characteristics to successfully perform critical work tasks, specific functions or operate in a given role or position. Such personnel characteristics may include mental/intellectual/cognitive, social/emotional/attitudinal and physical/psychomotor attributes necessary to perform the job (Dubois, 2013). Fogg (2009) extends the above definition to include both internal and external constraints, environments and relationships related to the job or occupation. Motivations and perceptions of the work and oneself or talent also as viewed as influential incompetently and successfully performing in a position or job assignment (McLean and Braden, 2006). In summary, competencies are specific personal qualities that are causally related to effective and/or superior performance (Boyatzis, 1982).

On the other hand, productivity is the output in goods and services of an organization relative to the expended resources. It is the capacity or situation whereby an individual or organization produces maximum results with available human, financial, and material resources to achieve organizational objectives (Egbo and Okeke, 2009). Herman (1987) in Egbo and Okeke (2009) defines productivity as output of goods and services per unit of resources used in the production process. Inputs as applied in the measurement of productivity, to Ivancevich (2001) are "expressions of the physical or dollar amount of several elements used in producing a good or a service, including labour, capital, material and energy." However, to be productive in the organization, an employee should first possess the requisite professional and technical competencies for his or her job; second, he/she should operate with the appropriate technology and tools; and more importantly, he/she must be well motivated through the provision of both 
economic rewards and conducive operational milieu that engenders positive social working relationships.

\section{Theoretical Framework}

The theory upon which this study was anchored is the McClleland's postulation of 'Testing for Competence rather than for intelligence.' In his article in 1973, McClleland had stated that the traditional tests of academic aptitude and knowledge content, in fact predicts neither job performance nor success in life. He argues further that traditional academic examination and IQ tests were no good ways of assessing whether a candidate seeking employment would or would not do well on specific job assignment. But people and even managers have continued to believe in them and as such have continued to use them on the basis of the incorrect assumption that such tests measure intelligence that would promote success in any job assignment.

He stresses that managers of human resource should rather seek ways of identifying other variables - "competencies" that can predict job success and performance. He opines that the demand and supply of human resource in any organization requires that an analysis of current situation and the estimate for the desired level be carried out since they are part of the determinants of the competency-based employee interview model. He remarks that managers of human resource in the organizations should always ensure due process and diligence in the demand and supply since they are critical factors in the actualization of the organizations' objectives. The competency approach to selection and assessment is based on classifying, identifying and measuring individual differences for particular work-related constructs that are relevant to successful job performance (Bartram, 2004).

\section{Theoretical Exposition}

Competency-based interview approach is commonly used to standardize and reduce subjectivity interviewing, which in turn strengthens the interview process and increases the validity of information gathered. It focuses on critical competencies (or specific job related criteria) and seeks to obtain objective information from candidates through specific past examples (Lewis, 2005). He describes competency-based interview model as a technique which is being used increasingly in large organizations for interviewing of some type of position. He added that it can sometimes be referred to as 'structured interviewing' or 'evidence-based interviewing' and there are two common approaches: one is to ask a series of questions targeted at each of the core competencies while the other requires in-depth probing questions with the interviewer actively listening for clues which provide evidence that the candidate possesses the necessary skills or competencies.

The use of competency-based interview is undoubtedly on the increase but many organizations have failed to adopt best practices because they are still holding strongly to the conventional method of recruitment. It is a development which Biu (2005) did not quite welcome. In his opinion, while traditional or conventional selection method focuses on skills, knowledge and education of the candidate, competency-based interview model is about analyzing an individual's core being-personality traits, competencies and assessing how well these elements can integrate well into the organization's corporate culture. Highway Agency (2007) notes that research into recruitment and selection methodology suggests that structured competencybased interviews can be one of the most reliable and accurate forms of assessment. 
The effect of use of unilateral power on organization's productivity which entails using forms of influence to obtain compliance is an outstanding competency. This is because it is concerned with power to have impact on others, it is also about reputation and status. To be able to influence opinion, there must be self-confidence about ability and will to achieve. Onukogu (2008) notes that as one of the core competencies, use of unilateral power to obtain compliance or influence opinions, is about leadership. It has to do with total and effective control of situations and events, helps to develop others and being decisive in all issues aimed at increasing productivity in the organization.

Similarly, competency of positive regard implies having a basic belief in others; freely or easily, sometimes making quick or snap decisions. It is about promptness in decision making . It is an active element of teamwork behaviour that enhances organization performance towards improved productivity (Leshem and Trafford, 2007). Organizations look for competent personnels that can perform assigned tasks competently and help towards the realization of the organizations goals. Such employees have energy and drive, enthusiastic about their work, they take the initiative, they are self-motivated and committed to the course of the organization. Competencies of use of unilateral power and positive regard are some of the core competencies that organizations sought after (Dehamare and Winterton, 2010).

\section{Empirical Review}

Rahmah and Syahida (2010) conducted a study on competency based employee interview process in Malaysian private sector to determine its effect on organizational performance. The study which adopted descriptive survey design found that competency-based interview have significant effect on performance. It was concluded that emphasis on competency implies development of human capital in the organization. In another study, Ainon (2003) examined the relationship between known individual competencies of employees and their performance in a wood-based industry and chemical production. The study was designed as a descriptive survey and the result from data analysis indicated that competencies are strongly related to performance both as individuals and between teams in the organization. The study concluded that employee competencies are major factors in the achievement of organizational goals.

In a related study, Sutherland (2011) carried out a study to determine the effect of recruitment practice of an organization on the performance of the employee. The study was a descriptive survey design. The result showed that positive and strong relationship exists between competencies of their employees and their performance. The study concluded that competency based employee recruitment reflects the mission and vision of the organization in terms of performance of the employees and goals achievement of the organizations goals . Also, Raisova (2012) did a study to compare the effectiveness of the competency-based interview model and the behavioural event interview. A large Czech financial sector firm was used for the study. The study adopted descriptive survey design and found from the analysis of data that the managers selected through competency-based interview achieved significantly better performance than those of behavioural event method. The study concluded that management should endeavour to always recruit workers through competency based tests. 


\section{METHODOLOGY}

\section{Research Design}

The study adopted a descriptive survey design because the data was principally primary and the results from the analysis would be generalized for the entire population of interest. Besides this, Obasi (2000) noted that the use of survey is always adopted because it provided an important means of gathering information, especially when the necessary data cannot be found in any statistical records in form of secondary data (official statistics).

\section{Area of the Study}

The study took place in Anambra State, Nigeria. The subject area was the evaluation of effect of competencies of use of unilateral power and that of positive regard on organizational productivity.

\section{Nature and Sources of Data}

The data was principally primary in nature and they were collected directly from the respondents through the administration of survey instrument (questionnaire). However, the primary data was supplemented with secondary data sourced from journal publications, textbooks and other academic works.

\section{Population of the Study}

The population of the study consists of 1,957 senior employees identified from selected primate sector organizations located across the three industrial zones of Awka, Onitsha and Nnewi in Anambra State.

\section{Sample and Sampling Technique}

Sample size for the study was determined through the application of Yaro Yamane's statistical formula for determining sample size from a finite population. The procedure is as follows:

$n=\frac{N}{1+N(e)^{2}}-\cdots-\ldots-\cdots-1(1)$

Where:

$$
\begin{array}{ll}
\mathrm{n} & =\text { Sample size to be determined } \\
\mathrm{N} & =\text { Entire population of interest } \\
\mathrm{e} & =\text { error margin }(0.05) \\
1 & =\text { Constant (unity) }
\end{array}
$$

Substituting in the formula, we have:

$$
\begin{aligned}
n & =\frac{1957}{1+1957(0.05)^{2}} \\
& =332.117098
\end{aligned}
$$

$$
n=332 \text { (Nearest whole number). }
$$

Thus 332 is the sample size for the study. 
Global Journal of Human Resource Management

Vol.8, No.1, pp.46-61, February 2020

Published by ECRTD-UK

Print ISSN: 2053-5686(Print), Online ISSN: 2053-5694(Online)

\begin{tabular}{lllll}
\multicolumn{2}{l}{ Table 1: } & Population and Sample Distribution & \\
\hline S/N & Zone & Population & $\begin{array}{l}\text { Sample } \\
\text { Allocation }\end{array}$ & $\begin{array}{l}\text { Percentage } \\
\text { of Total }\end{array}$ \\
\hline 1. & Awka & 573 & 97 & 29.3 \\
2. & Onitsha & & & \\
3. & Nnewi & 683 & 116 & 34.9 \\
\hline & Total & 701 & 119 & 35.8 \\
\hline
\end{tabular}

Source: Field Survey, 2019

In terms of selection of units of observation, systematic sampling technique was used because of its ability to evenly spread the sample across the population of interest. As could be seen from Table 1, the sample was allocated across the zones proportionately because of the differences in their population.

\section{Instrument for Data Collection}

An item structured instrument developed to reflect the five (5) point modified Likert scale was used to elicit information from the respondents across the zones.

\section{Validity and Reliability of the Instrument}

The instrument was both face and content validated by some experts who are quite knowledgeable in questionnaire drafting. Their corrections and comments were reflected in the final draft of the questionnaire. On the other hand, the reliability of the instrument was determined through the test re-test method. The coefficients for the two research questions were respectively 0.88 and 0.70 (see details of estimation in the Appendix). Thus showing an average coefficient of 0.79 meaning that the instrument is 79 percent reliable. This was considered adequate for the study.

\section{Methods of Data Collection and Analysis}

Direct questionnaire distribution approach was adopted by the researcher and it afforded him the opportunity of assessing whether the respondents actually understood the questionnaire items. The method also reduced the volume of non-response which often associate with surveys of this nature. Out of the 332 copies of the questionnaire issued out, 321 were completed and returned thus showing a response rate of 99.69 percent.

The data were analyzed quantitatively through the application of Pearson correlation coefficient and Ordinary Least Squares (OLS) multiple regression analysis. All tests were conducted at 0.05 level of significance. This being the probability level at which we were willing to risk type I error.

\section{Model Specification}

The study seeks to determine the effect of competency-based interview process on organizational productivity. Consequently, the functional relationship between the dependent and independent variables are specified as follows: 
$\mathrm{FP} \quad=\mathrm{F}(\mathrm{UUP}, \mathrm{PR})-$

Specifying econometrically, we have:

$\mathrm{FP}=\alpha_{\mathrm{o}}+\alpha_{1} \mathrm{UUP}+\alpha_{2} \mathrm{PR}+\mu_{\mathrm{t}}-$

Where:

$$
\begin{array}{ll}
\mathrm{FP} & =\text { Firm's productivity } \\
\alpha_{\mathrm{o}} & =\text { The intercept } \\
\mu_{\mathrm{t}} & =\text { Stochastic error } \\
\mathrm{UUP} & =\text { Use of unilateral power } \\
\mathrm{PR} & =\text { Positive regard } \\
\alpha_{\mathrm{i}^{\prime} \mathrm{s}} & =\text { the coefficients }
\end{array}
$$

The expected signs or a priori are as follows:

$\alpha_{1}>0$ and $\alpha_{2}>0$

This implies that positive relationship is expected between the dependent and independent variables.

\section{DATA PRESENTATION AND ANALYSIS}

\section{Correlation Analysis}

Pearson correlation technique was used to run a matrix to ascertain the relationship between the dependent and independent variables, as well as ascertain whether there is presence of multi-collinearity or orthogonal relationships. The matrix is presented below:

\section{Table 2: Correlation Matrix}

Correlation Matrix

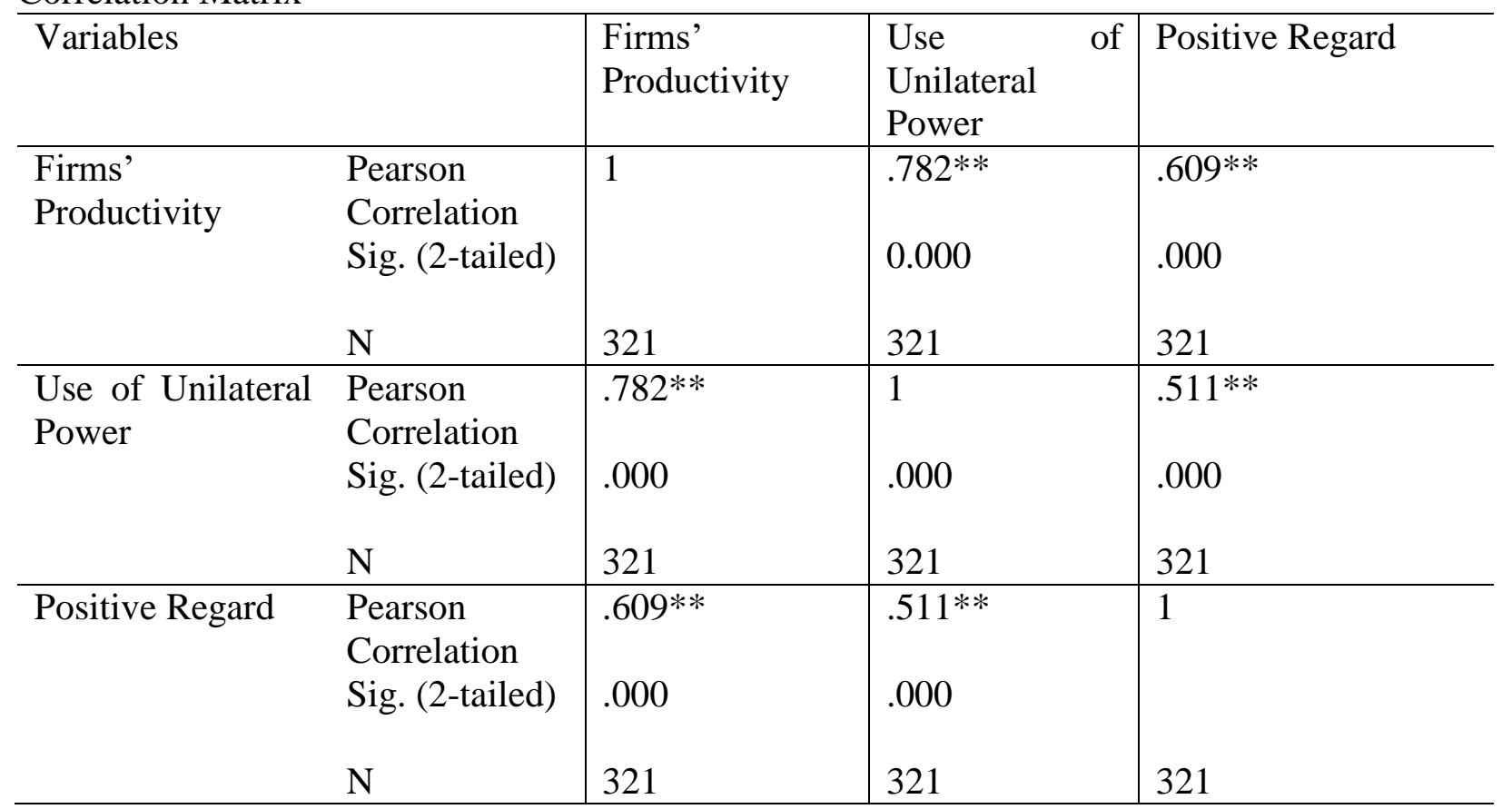

** Correlation is significant at 0.05 level (2-tailed).

* Correlation is significant at 0.01 level (2-tailed).

The correlation matrix in Table 2 shows that positive and strong relationship exists between and among dependent and independent variables. The result did not present any multi- 
Global Journal of Human Resource Management

Vol.8, No.1, pp.46-61, February 2020

Published by ECRTD-UK

Print ISSN: 2053-5686(Print), Online ISSN: 2053-5694(Online)

collinearity or orthogonal relationships. Thus indicating that regression analysis can be carried out on the data.

Table 3: Summary of Analysis of Variance (ANOVA)

ANOVA $^{\text {b }}$

\begin{tabular}{|c|c|c|c|c|c|}
\hline $\begin{array}{l}\text { Source } \\
\text { Variation }\end{array}$ & of $\mathrm{df}$ & $\begin{array}{l}\text { Sum of } \\
\text { Squares }\end{array}$ & Mean Square & F-ratio & Sig. \\
\hline Regression & 4 & 78.156 & 19.539 & 16.296 & $.000^{\mathrm{a}}$ \\
\hline Residual & 45 & 53.967 & 1.199 & - & \\
\hline Total & 49 & 132.123 & & & \\
\hline
\end{tabular}

a. Predictor: (constant), Use of unilateral power and positive regard

b. Dependent variable: Firms' Productivity

From Table 3, it could be seen that F-value is 16.296 and it is significant because 0.05 significance level is greater than 0.000 probability level. The implication is that overall, regression model is statistically significant, stable, valid and fit for predictions.

Table 4 : Summary of Regression Results

\begin{tabular}{|l|l|l|l|l|}
\hline Model & $\mathrm{R}$ & $\mathrm{R}^{2}$ & Adjusted $\mathrm{R}^{2}$ & $\begin{array}{l}\text { Standard Error of } \\
\text { the Estimate }\end{array}$ \\
\hline $\mathrm{I}$ & $0.791^{\mathrm{a}}$ & 0.705 & 0.701 & 0.69578 \\
\hline
\end{tabular}

a. Predictor: (constant), Use of unilateral power and positive regard

The summary of regression results presented in Table 4 shows that regression coefficient represented by $\mathrm{R}$ has the value of 0.791 and it means that 79.1 percent relationship exists between dependent and independent variables. Similarly, the coefficient of determination represented by ' $\mathrm{R}^{2}$ ' has the value of 0.705 and it means that about 70.5 percent variation in the dependent variable firms' productivity, can be explained by the independent variables.

Table 5: $\quad$ Summary of Variable Coefficients, t-value and the Significance Level

\begin{tabular}{|c|c|c|c|c|c|}
\hline Model & $\begin{array}{l}\text { Unstar } \\
\text { Coeffi }\end{array}$ & $\begin{array}{l}\text { ized } \\
\text { s }\end{array}$ & $\begin{array}{l}\text { Standardized } \\
\text { Coefficients }\end{array}$ & $\mathrm{t}$ & Sig. \\
\hline & $\beta$ & Std. Error & Beta & & \\
\hline 1(Constant) & -.162 & .205 & - & -620 & .390 \\
\hline Use of Unilateral Power & .517 & .051 & .721 & 3.027 & .000 \\
\hline Positive Regard & .528 & .047 & .436 & 3.615 & .000 \\
\hline
\end{tabular}

a. Dependent Variable: Firms' Productivity

\section{Test of Hypotheses}

The hypotheses formulated to guide the objectives of the study and strengthen the analysis, were verified in this section of the analysis through the results of the regression analysis as presented in Table 5. 


\section{Re-Statement of the Hypotheses}

1. $\mathrm{H}_{\mathrm{O}}$ : Competency of use of unilateral power does not have positive and significant effect on organizational productivity.

$\mathrm{H}_{1}$ : Competency of use of unilateral power have positive and significant effect on organizational productivity.

2. Ho: Competency of positive regard does not have positive and significant effect on organizational productivity.

$\mathrm{H}_{1}$ : Competency of positive regard have positive and significant effect on organizational productivity.

\section{Interpretation of Regression Results}

The coefficient of use of unilateral power represented by $\alpha_{1}$ has the value of 0.721 and it means that when use of unilateral power is increased by one unit, firm's productivity will increase by 7.2 percent if other variables in the model are held constant. The t-value of 3.027 and the corresponding probability level of 0.000 shows that the coefficient is significant because 0.000 is less than 0.05. Consequently, the null hypothesis was rejected while the alternative which suggests that competency of use of unilateral powers have positive and significant effect on firm's productivity was accepted.

In the same vein, the coefficient of positive regard represented by $\alpha_{2}$ in the model, has the value of 0.436 and it means that increase in positive regard by one unit will lead to increase in firm's productivity by 4.4 percent when other variables in the model are held constant. Also, the tvalue of 3.615 and its corresponding significance level of 0.000 shows that the coefficient is significant given that 0.000 is less than 0.05 . Consequently, we rejected the null hypothesis and accept the alternative which suggests that competency of positive regard have positive and significant effect on firm's productivity.

\section{DISCUSSION OF RESEARCH RESULTS}

The discussion in this section was based on the results of test of hypotheses. The result of the first test of hypothesis indicates that the use of unilateral power that involves using various forms of influence to obtain compliance, have positive and significant effect on firm's productivity. Such competency can really affect performance because it comes from individual's unique characteristics. Just as Robbins and Judge (2007) had observed, both expert and referent power are positively related to employees' satisfaction with supervision, their organizational commitment and their performance. It becomes ideal therefore that managers should look out for personalities with such competencies for employment through the competency based interview and model.

The result of hypothesis two shows that competency of positive regard that is, having a basic belief in others; freely or easily, sometimes making quick or snap decisions, actually have positive and significant effect on firm's productivity. The characteristics or elements of this competency reinforces the need for teamwork among the employees in order to impact organizational productivity. The belief in others is all about trust among team members, 
confidence in each other's competencies. Cooperation and unity among employees produces high performing employees in the workplace. Criticisms are easily taken and opinions are freely expressed, an environment that releases the inner ability of the employees to produce more than expected.

\section{Summary of Findings}

The preliminary results shows that regression model is statistically significant, stable, valid and fit for predictions with the F-Statistic of 16.296. The regression coefficient which was 0.791 shows that 79.1 percent relationship exists between the dependent and independent variables. Also, the coefficient of determination represented by ' $\mathrm{R}^{2}$ ' with a value of 0.705 shows that 70.5 percent variation in the dependent variables firm's productivity, can be explained by the predictor variables. More specifically, the rest of the results are summarized as follows:

1. Possession of use of unilateral power by an employee can actually lead to improved organizational productivity. It was found that unilateral power attribute promotes followership even among colleagues because the owner controls what others do not have.

2. Possession of competency of positive regard enhances organizational productivity. This is because in teamwork which this kind of competency promotes, issues can be raised and discussed freely. There is trust and criticisms are accepted without grudges.

\section{CONCLUSION}

The study examined the effect of competency based employee interview model on organizational productivity, using selected private sector organizations in Anambra State, Nigeria. The findings indicate that the competency-based employee interview model is more effective than the behavioural event or conventional method in terms of effect on employee performance as well as firm's productivity. This is because identifications of competencies in the prospective employees help the organization to appropriately select and place the employee where they are best suited in the organization. Also, the competency cluster which Boyatzis (1982) referred to as the "threshold competencies" are not usually identified in candidates seeking employment during behavioural event interviews.

\section{Recommendations}

Based on the findings and the conclusions made from the study, the following recommendations were made:

1. Given the potency of competency of use of unilateral power as could be seen from the coefficient, management should endeavor to always seek an employee personality with such attributes.

2. Organizations should endeavor to utilize the competency-based employee interview model so that they can identify competencies such as positive regard and other core competencies used in engaging the prospective employees for effective performance and attainment of organizational goals.

\section{REFERENCES}

Ainon, M. (2003). Employee competencies and performance: a study of selected firms in Chiba city, Japan. Business and Economic Horizons, 3(5): 61-74.

Akinnukawe, E. (2005). Recruitment and selection system. Lagos: Lagos Business School. 
Akuezuilo, E.O. and Agu, N. (2007). Research and statistics in education and social sciences: method and application. Awka: NuelCenti Publishers and Academic Press.

Armstrong M. (1998). Managing people: a practical guide for line managers, London: Kogan Page Ltd.

Bartran, D. (2004). Assessment in organization applied psychology:An International Review, 53(2): 237-259.

Biu, O. (2005). The competency-based approach. Lagos: Lagos Business School.

Boyatzis, R. (1982). The competent manager. A model for effective performance. New York: John Wiley and Sons.

Delamare, L.F. and Winterton, J. (2010). What is competence? Human Resource Development International, 8(1): 27-46.

Dubois, D.D. (2013). Competency-based performance improvement: a strategy for organizational change, Amherst, MA: HRD Press Inc.

Egbo, E.A. and Okeke, M.I. (2009). Foundations of personal management in Nigeria. Enugu: Bismark Publications.

Fogg, C.O. (2009). Implementing your strategic plan: how to turn intent into effective action for sustainable change. New York: American Management Association.

Herman, A.S. (1987). Productivity gains continued in many industries during 1985. In Egbo, E.A. and Okeke, I.M. (eds.). Foundations of personal management in Nigeria. Enugu: Bismark Publications.

Highway Agency (2008). Competency-based interviews. London: cited in http://www.highways.gov.uk

Ivancevich, J.M. (2001). Human resource management, Eight Edition. Boston: McGraw-Hill. Leshem, S. and Trafford, V. (2007). Overlooking the conceptual framework. Innovation in Education and Teaching International, 44(1): 93-105.

Lewis, A. (2005). Competency-based interview questions made easy. Cited in http://www.file://E:/competency.

Lucia, A.D. and Lepsinger, R. (2009). The art and science of competency models: pinpointing critical success factors in organizations. New York: Pfeiffer.

Maile, J. (2007). The competency-based behavioural interview. London: Georgia Merit System.

Marchington, M. and Wilkonson, A. (2006). Human resource management at work: people management and development (3rd ed.). London: Chartered Institute of Personnel and Development.

McClelland, D.C. (1973). Testing for competence rather than for intelligence. AmericanPsychology, 28:1-14.

Miller, T. (2000). Redesigning human resource for strategic advantage: how human resource department can deliver measurable values. London: Pearson Education Ltd.

Obasi, I.N. (2000). Research methodology in political science. Enugu: Academic Publishing Company.

Onukogu, C.O. (2006). Dynamics of modern management: the secrets of producing managers who build and lead organizations. Lagos: Impressed Press Ltd.

Rahmah, I. and Syahida, Z.A. (2010). Impact of workers competency on their performance in Malaysian private service sector. Peer Reviewed and Open Access Journal, 2(2): 2536. 
Raisova, T. (2012). The comparison between the effectiveness of the competency-based interview and the behavioural event interview. Human Resource Management and Ergonomics, Vol. vi.

Rohtas, K., Sarang, C., Jagdale, A., Kuma, G. and Jaiy, A. (2013). Understanding employee cycle through exit interviews: conceptual framework and case illustration. Indian Institute of Management, Bangalore, India.

Simonson, P. and Smith, T. (2007). Competency-based behaviour interviewing, London: cited in http://www.careertrainer.com

Sutherland, W. (2011). Effective recruitment process: a framework for outstanding employee performance. International Journal of Selection and Assessment, 7(3): 142-156.

Torrington, D., Hall, L. and Taylor, S. (2005). Human resource management (6th ed.). Hempstead: Prentice Hall.

\section{APPENDIX I}

Use of Unilateral Power and Employee Performance

\begin{tabular}{|c|c|c|c|c|c|c|}
\hline \multirow[t]{2}{*}{$\mathrm{S} / \mathrm{N}$} & \multirow[t]{2}{*}{ Item } & \multicolumn{4}{|c|}{ Alternative Responses } & \multirow[t]{2}{*}{ Total } \\
\hline & & SA & $\mathrm{A}$ & $\mathrm{D}$ & UND & \\
\hline 1. & $\begin{array}{l}\text { Using forms of influence to obtain compliance } \\
\text { from individual colleague or groups can enhance } \\
\text { performance. }\end{array}$ & & & & & \\
\hline 2. & $\begin{array}{l}\text { Use of unilateral power as individual employee } \\
\text { attribute makes an employee stand out in task } \\
\text { accomplishment. }\end{array}$ & & & & & \\
\hline 3. & $\begin{array}{l}\text { This is a power that an employee wields over } \\
\text { his/her colleagues, it comes from individual's } \\
\text { unique characteristics which enhances } \\
\text { performance. }\end{array}$ & & & & & \\
\hline 4. & $\begin{array}{l}\text { The unilateral power attribute promotes } \\
\text { followership even among colleagues because the } \\
\text { owner controls what others do not have. }\end{array}$ & & & & & \\
\hline 5 . & $\begin{array}{l}\text { Leaders achieve goals in an organization and } \\
\text { power is a means of facilitating their } \\
\text { achievements. }\end{array}$ & & & & & \\
\hline & Total & & & & & \\
\hline
\end{tabular}

Note: (SA: Strongly agree; $\mathrm{A}=$ Agree; $\mathrm{D}=$ Disagree; $\mathrm{SD}=$ Strongly Disagree and UND = Undecided)

Competency of Positive Regard and Employee Performance

\begin{tabular}{|l|l|l|l|l|l|l|l|}
\hline S/N & Item & \multicolumn{3}{|l|}{ Alternative Responses } & Total \\
\cline { 3 - 6 } & & SA & A & D & SD & UND & \\
\hline 1. & $\begin{array}{l}\text { Belief in others makes for effective } \\
\text { teamwork in an organization. }\end{array}$ & & & & & & \\
\hline 2. & $\begin{array}{l}\text { It leads to quick or snap decisions } \\
\text { without much arguments. }\end{array}$ & & & & & & \\
\hline 3. & $\begin{array}{l}\text { Trust among the team members comes } \\
\text { when members of the team develop the } \\
\text { confidence in each other's competencies }\end{array}$ & & & & & & \\
\hline
\end{tabular}


Print ISSN: 2053-5686(Print), Online ISSN: 2053-5694(Online)

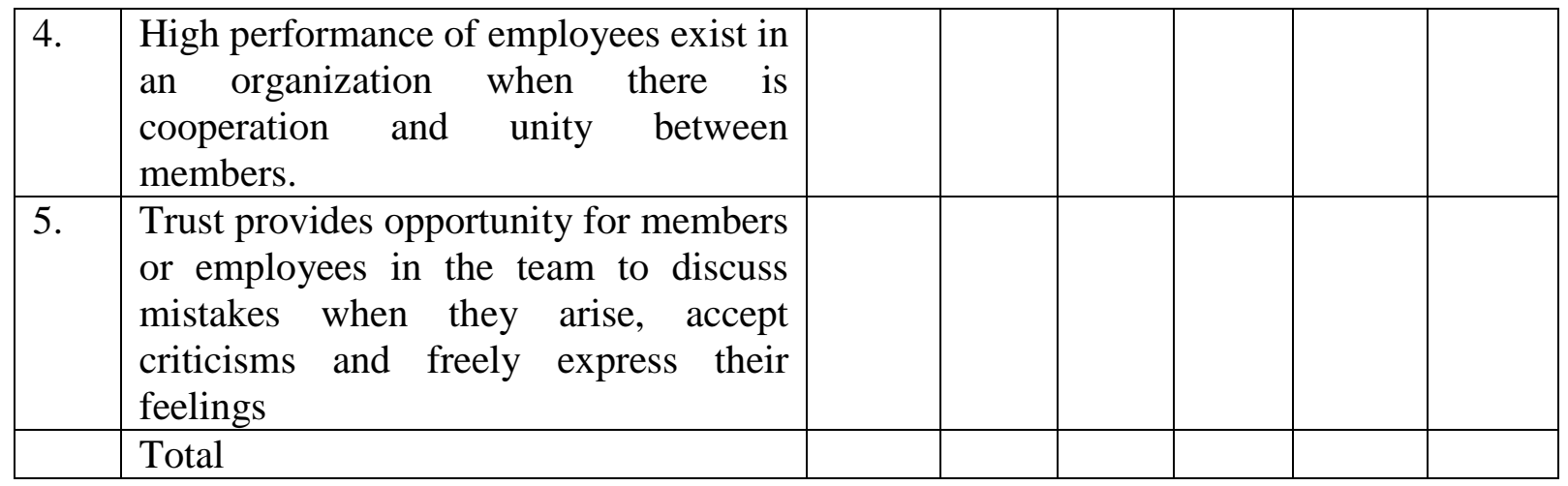

Note: (SA: Strongly agree; $\mathrm{A}=$ Agree; $\mathrm{D}=$ Disagree; $\mathrm{SD}=$ Strongly Disagree and UND = Undecided)

\section{APPENDIX II}

\section{RELIABILITY TEST FOR THE INSTRUMENT}

Reliability test was carried out to ascertain the adequacy and suitability of the questionnaire designed to facilitate data collection from the respondents. In the light of this, the study being an empirical one, adopted a test re-test method of reliability test. Spearman rank order correlation coefficient was used to analyze the first and second responses from the 50 respondents selected for the test. The formula for Spearman rank order correlation coefficient is given as:

$$
r=1-\frac{6 \sum d^{2}}{n\left(n^{2}-1\right)} \ldots \ldots-\ldots
$$

Where:

$$
\begin{aligned}
& \mathrm{r} \quad=\text { Coefficient of Correlation } \\
& \mathrm{n} \quad=\text { Number of response options } \\
& \mathrm{d} \quad=\text { Difference in rank } \\
& 1 \text { and } 6=\text { Constant }
\end{aligned}
$$

The value of the coefficient (r) ranges from -1 to +1

Estimation of Reliability for Research Question 1

\begin{tabular}{lllllll}
\hline Response Option & $\begin{array}{l}\text { Result of } 1^{\text {st }} \\
\text { Interview (x) }\end{array}$ & $\begin{array}{l}\text { Result of } 2^{\text {nd }} \\
\text { Interview (y) }\end{array}$ & Rx & Ry & $\begin{array}{l}\text { Rx }- \text { Ry } \\
(\mathrm{d})\end{array}$ & $\mathrm{d}^{2}$ \\
\hline Strongly agree & 22 & 20 & 1 & 2 & -1 & 1 \\
Agree & 20 & 21 & 2 & 1 & 1 & 1 \\
Disagree & 2 & 3 & 4.5 & 4 & 0.5 & 0.25 \\
Strongly disagree & 4 & 5 & 3 & 3 & 0 & 0 \\
Undecided & 2 & 1 & 4.5 & 5 & 0.5 & 0.25 \\
\hline Total & 50 & 50 & & & & 2.5 \\
\hline
\end{tabular}

$$
\begin{aligned}
& r=1-\frac{6(2.5)^{2}}{5\left(5^{2}-1\right)} \\
& r=1-\frac{15}{120}=0.88
\end{aligned}
$$


Global Journal of Human Resource Management

Vol.8, No.1, pp.46-61, February 2020

Published by ECRTD-UK

Print ISSN: 2053-5686(Print), Online ISSN: 2053-5694(Online)

Estimation of Reliability for Research Question V

\begin{tabular}{lllllll}
\hline Response Option & $\begin{array}{l}\text { Result of } 1^{\text {st }} \\
\text { Interview (x) }\end{array}$ & $\begin{array}{l}\text { Result of 2 } \\
\text { Interview (y) }\end{array}$ & Rx & Ry & $\begin{array}{l}\text { Rx }- \text { Ry } \\
(\mathrm{d})\end{array}$ & $\mathrm{d}^{2}$ \\
\hline Strongly agree & 20 & 20 & 2 & 2 & 0 & 0 \\
Agree & 21 & 22 & 1 & 1 & 0 & 0 \\
Disagree & 3 & 5 & 4 & 3 & 1 & 1 \\
Strongly disagree & 5 & 1 & 3 & 5 & -2 & 4 \\
Undecided & 1 & 2 & 5 & 4 & 1 & 1 \\
\hline Total & 50 & 50 & & & & 6 \\
\hline
\end{tabular}

$r=1-\frac{6(6)}{5\left(5^{2}-1\right)}$

$r=1-\frac{36}{120}=0.70$ 